Vol. 5 No. 1, January 2021, pp. 1-21

\title{
Hindu Legal Philosophy in Ngelinggihang Dewa Hyang Tradition: A Case Study in Jero Kuta Customary Village
}

\author{
Dewa Ketut Wisnawa* \\ Faculty of Dharma Duta, I Gusti Bagus Sugriwa State Hindu University, \\ Bali - Indonesia
}

\begin{abstract}
This article discusses Ngelinggihang Dewa Hyang ceremony in Gianyar Regency which is different from the traditions in other regions in Bali. This tradition originates from Hindu law but is implemented differently by each customary village. This study aims to assess the position of Hindu law in Indonesian legislation, discuss Hindu law as the basis for implementing Ngelinggihang Dewa Hyang ceremony, identify the autonomy of customary village in Ngelinggihang Dewa Hyang process, and reveal the public perceptions of this ceremony in Jero Kuta Customary Village, Batubulan Village, Sukawati District, Gianyar Regency. This paper is a socio-religious research that is combined with a legal research. The research suggested that Hindu law does not have an explicit position in national law, but is used as the guideline for Balinese customary law. Sources of Hindu law used in this ceremony are Lontar Purwa Bhumi Kamulan and Manawa Dharmasastra that have been derivated into customary law. The autonomy of the customary village in the process of Ngelinggihang Dewa Hyang can be seen from the dresta (customary law) adopted by the villagers of Jero Kuta Customary Village who carry out this procession on a different day from other rituals. The public perception of this ceremony can be seen from the interaction in family and community scope. It has been revealed that the society does not fully understand the meaning of this religious procession due to the following factors; differences in community understanding of the existence of the Ngelinggihang Dewa Hyang ceremony; ignorance of the community, education Level, and the development of globalization in people's life.
\end{abstract}

Keywords: Hindu law; Ceremony; Customary village; Autonomy; Bali.

\section{INTRODUCTION}

\subsection{Background}

Indonesia is a very pluralistic country from all aspects (ethnicity, race, group, and religion). After the political reform, the state and law paradigm have shifted from centralization into decentralization as reflected in the Amendment to the 1945 Constitution of the Republic of Indonesia (hereinafter, Indonesian Constitution) regarding the recognition of customary communities along with their traditional rights. ${ }^{1}$ The \footnotetext{
$\begin{array}{ll}* * & \text { Email/Corresponding } \\ \text { dewaketutwisnawa88@gmail.com } & \text { Author: } \quad \text { wisnawadewa94@uhnsugriwa.ac.id }\end{array}$

1 Syamsudin,"Beban Masyarakat Adat Menghadapi Hukum Negara." Jurnal Hukum Ius Quia Iustum 15, no.3 (2008): 338-35). Recognition of indigenous people has existed since the independence of the Republic of Indonesia. See also Luh Putu Yeyen Karista Putri, and Eric Gordon Withnall, "Protecting the Village Credit Institution: Should Traditional
} 
Constitution awards them certain constitutional rights including rights to own territory, autonomous governmental system, people, and legal system. ${ }^{2}$ Article 18B of the Indonesian Constitution provides a juridical construction regarding the unitary community of customary community. ${ }^{3}$

Bali is a province in Indonesia that has a unique governmental system. Bali as one of the provinces in the Unitary State of the Republic of Indonesia is subject to national law, namely a written law made by a legitimate state body. ${ }^{4}$ Besides the existence of village $($ desa) in Bali that has a similar structure with other villages in other regions in Indonesia, Bali there has also been existed what so-called desa adat (customary village) in Bali for centuries. The legitimacy of customary villages in Bali is regulated in the Bali Provincial Regulation No. 4 of 2019 concerning Customary Villages in Bali. This regulation defines desa adat (customary village) as follows:

"a customary law community unit in Bali that has territory, position, original arrangement, traditional rights, own assets, traditions, social life rules for generations, inherited in the bond of a holy place in this case kahyangan tiga or kahyangan desa (three main temples situated in village), duties and authority and the rights to regulate and manage their own households. ${ }^{5}$

This customary village is entitled to create an autonomous regulation that primarily aims to advance customs, traditions, arts and culture, and local wisdom of the customary villagers in Sakala (real life) and niskala (noetic/spiritual life) as well as realizing krama desa adat (customary villagers) who can maintain social unity as part of national security in accordance with the philosophy of Tri Hita Karana (three causes to prosperity). ${ }^{6}$ To value this philosophy, the customary people carry out various religious ceremonies to purify the soul, people, and the universe. The principle of Tri Hita Karana is considered capable of building harmony and balance between the worship of God, human relationships with each other, and the environment. ${ }^{7}$

One of Hinduism teachings is regarding how the ceremony should be properly conducted for a dead person. A Hindu text Lontar Siwa Tattwa

Communities Adopt Modern Financial Management Practices?, Udayana Journal of Law and Culture 2, no. 2 (2018): 122.

${ }^{2}$ Hanna Christine Ndun, Sarah Suttor, and I Gusti Agung Ayu Dike Widhiyaastuti, "Does Customary Law Discriminate Balinese Women's Inheritance Rights?," Udayana Journal of Law and Culture 2, no.1 (2018): 98.

3 Lalu Sabardi, "Konstruksi Makna Yuridis Masyarakat Hukum Adat dalam Pasal 18B UUDN RI Tahun 1945 untuk Identifikasi Adanya Masyarakat Hukum Adat," Jurnal Hukum \& Pembangunan 44, no. 2 (2014): 170-196.

4 I Nengah Lestawi and Dewi Bunga, "The Role of Customary Law in the Forest Preservation in Bali," Journal of Landscape Ecology 13, no.1 (2020): 25-41. Art. 1(8)

${ }^{5}$ Bali Provincial Regulation No.4 of 2019 concerning Customary Villages in Bali,

${ }^{6}$ Ibid., Art. 3(1)

7 Widyantara, et al., "Environment Dispute Resolution through Awig-Awig (Customary Law)," JL Pol'y \& Globalization 70 (2018): 75. 
Purana guides Ngaben as a Balinese cremation ceremony. 8 There are several types of Ngaben sacred rituals, from the main majestic ritual to simple versions of such. ${ }^{9}$ In Ngaben procession, there is a ceremony called Sawa Wedana. The aim of Sawa Wedana ${ }^{10}$ is to restore the elements of the Panca Maha Bhuta (the five elements found in the human body namely earth (soil), water, air, fire, and space) ${ }^{11}$ and purify the soul of a person who has passed away.

Practices show that the dead body of a Hindu in Bali are generally cremated or buried. According to Hindu-Bali, there are a series of rituals after cremation or burial. If the cremation or burial ceremony has been executed, then it will be continued with Ngelinggihang Dewa Hyang or Nyekah. Hinduism in Bali has a belief in Dewa Hyang or Dewa Pitara which is an ancestral spirit that has reached the realm in Swah Loka (the realm of the Gods). To reach the stage of Dewa Pitara, there are several ceremonies carried out namely the Ngaben ceremony and Ngelinggihang Dewa Hyang. ${ }^{12}$ According to the holy book Bhagawad Gita III.12, Ngelinggihang Dewa Hyang ceremony is aimed to free the ancestors from the bonds of sin and karma. This ceremony is carried out by increasing the pitara ${ }^{13}$ to become an ancestor and symbolically placed in a Merajan Kemulan/Sanggah Kemulan ${ }^{14}$ (a private temple at home.

It is commonly accepted that Nyegara Gunung ceremony (sacred journey or pilgrimage made from the sea to the mountain) is conducted before the Ngelinggihang Dewa Hyang. Most customary villages organize these two ceremonies on the same day. However, different ways are practiced in Jero Kuta Customary Village, Batubulan Village, Sukawati District, Gianyar Regency. It is a customary village that consists of eight banjar (a small unit of community in Bali) namely Banjars Pengembungan, Tegaljaya, Denjalan, Batur, Pagutan Kaja, Pagutan Kelod, Telabah, and Pengambangan. In this customary village, Nyegara Gunung and Ngelinggihang Dewa Hyang ceremonies are held on different days. The customary villagers consider that Nyegara Gunung ceremonies is still part of a series of Atma Wedana ceremonies that is classified as Pitra

8 I. Nyoman Kiriana, "Ngaben Conception In Lontar Siwa Tattwa Purana," Vidyottama Sanatana: International Journal of Hindu Science and Religious Studies 1 no.2 (2017): 86.

9 AA Ayu Oka Saraswati, and Paul Memmott, "The Child Misses Its Mother"-Balinese Place Experience of The Ngaben Ritual Event," Journal of Basic and Applied Scientific Research 4 no.5 (2014): 1.

10 Sawa Wedana is a cremation ceremony in Bali involving an intact corpse.

11 I Made Gami Sandi Untara, "Kosmologi Hindu Dalam Bhagavadgītā," Jñānasiddhânta: Jurnal Teologi Hindu 1, no. 1 (2019): 20.

12 Term Ngelinggihang Dewa Yang is generally called Ngasti or Nyekah. Besides, this ceremony is also called as Ngelinggihang Dewa Hyang ceremony is also called Devapitrapindha, Atmasiddhadevatà, or Nuntun Dewa Hyang. See Nararya Narottama, "Spiritual tourism: A case study of foreigners' participation in the Pitrayajna ceremony in the Desa Pakraman of Muncan, Selat, Karangasem, Bali," E-Journal of Tourism 3, no.1. (2016): 35.

13 Pitara means the spirits of the deceased. ancestors.

14 Merajan Kemulan/Sanggah Kemulan means family based-holy place for the 
Yadnya (offering to the ancestors), while Ngelinggihang Dewa Hyang is categorized as Dewa Yadnya (offering as an expression of gratitude to God). ${ }^{15}$ Even though the lives of Balinese peoples are similarly guided by Hindu law, the customary village has the autonomy to determine how the Ngelinggihang Dewa Hyang ceremony should be conducted, differ from other villages. Basically, each customary village has its own authority to decide the type, means, and method of conducting a ceremony. Simply, the same source of law, in this regards Hindu Law, does not mean that it must be implemented uniformly. In Bali, this is called as dresta, ${ }^{16}$ which may differ from the custom and tradition practice in other customary villages.

The practice indicates that Hindu Law may be dynamically interpreted by each entity, including the customary village, based on their common knowledge, belief, and agreement. Jero Kuta customary village has its own arrangements to determine the procedures and interpret the Ngelinggihang Dewa Hyang ceremony. As an example, the villagers will choose the day to conduct Ngelinggihang Dewa Hyang ceremony on the same day with piodalan $^{17}$ in the Merajan Kemulan. Before holding at Merajan Kemulan, his family made a temporary pelinggih (place of worship).

\subsection{Purpose}

The purpose of this research is aimed to analyze four issues. First of all, it assesses the position of Hindu law in Indonesian legislation and regulations. Second, it discusses Hindu law as the basis for implementing Ngelinggihang Dewa Hyang. Next, it investigates the autonomy of customary villages in the process of Ngelinggihang Dewa Hyang. Lastly, it reveals public perceptions of Ngelinggihang Dewa Hyang ceremony in Jero Kuta Customary Village, Batubulan Village, Sukawati District, Gianyar Regency.

\subsection{Method}

This research is a socio-religious research that is combined with a legal research. The socio-religious research is used to inquiry about the relevant Hindu teachings and Hindu Law with regards to the topic discussed in this paper and to present an analysis of how Hindus in Bali implement them in their social and cultural life. The legal research is used to add the legal aspects related to the position of Hindu Law in Indonesia, primarily in the region of Bali, and the legality of the customary village in Bali to create and adopt customary law that is inspired by Hindu teachings.

A socio-religious research was used in identifying the empirical conditions of the Ngelinggihiang Dewa Hyang Ceremony. Socio-religious

15 I Gusti Ketut Widana, "Filosofi Ritual Hindu, Pergeseran Antara Konsep dan Konteks," Dharmasmrti: Jurnal Ilmu Agama dan Kebudayaan 10, no.2 (2019): 29.

16 Dresta is a custom or tradition inherited from generation to generation and still adhered to by customary villages. Bali Provincial Regulation No.4 of 2019 concerning Customary Villages in Bali, Art. 1.

17 Piodalan can be explained as a ceremony related to the day of the establishment of the Merajan Kemulan 
research describes life narratives, rather than narratives consisting of texts, or translations, resulted in a real conditions in social reality in the community. ${ }^{18}$ An empirical study was conducted in the Customary Village of Jero Kuta, Batubulan Village, Sukawati District, Gianyar Regency to collect qualitative data, ${ }^{19}$ through are observation, interview, ${ }^{20}$ and documentation. The qualitative research in general aims to develop concepts or develop an understanding of a phenomenon, in this case, the phenomenon of Hindu religious rituals, specifically about the relevance of Ngelinggihiang Dewa Hyang ceremony in the teachings of Panca Yadnya (five kinds of holy offerings) in Jero Kuta Customary Village.

\subsection{Literature Review}

This research examines the implementation of customary village autonomy manifested in dresta as regulated in Regulation of Bali Provincial Regulation No.4 of 2019 concerning Customary Villages in Bali in organizing Ngelinggihiang Dewa Hyang ceremony in Jero Kuta Customary Village. Structural functional theory viewing that society as a functional system is in equilibrium condition known as the integration approach or more popularly known as the structural-functional approach. Structural-Functional Theory is analyzed by looking at society as a system of interactions between people and their various institutions and everything agreed by consensus including values and norms that emphasize harmony inconsistency and balance in the society.

Durkheim, Malinowski, and Radeliffe Brown are very influential figures in structural-functional theory. ${ }^{21}$ Starting from the speculation of Durkheim in functional theory stating: (1) society must be seen as a unit that can be distinguished from its parts, but cannot be separated; (2) the parts of a system function to fulfill the interests of the system as a whole; (3) functional interests are used in the normal and pathological sense, thus a social system must meet its own needs to prevent abnormal conditions; (4) by looking at the system normally, pathologically, and functionally, there are certain topics or points in which these things can be achieved so that functionalization normally proceeds around that point. ${ }^{22}$ This theory is used as a provision for the implementation of Hindu rituals, especially in Ngelinggihang Dewa Hyang ceremony held by a system of social cooperation in which all components of society have the same responsibility in creating and realizing security, comfort, and peace as a result of the ritual implementation.

18 Sumarto. "Creative Economic Management of Tangkit Lama Village Sungai Gelam Sub-District Muara Jambi District." HUNAFA: Jurnal Studia Islamika 15, no. 2 (2018): 323339.

19 See qualitative research methods in Hamidi. Metode Penelitian Kuantitatif. (Malang: Univaresitas Muhammadiyah, 2004), 25.

20 Interview is conducted with Jero Kuta Bendesa (leader) of Batubulan Village, Sukawati District, Gianyar Regency, 2018-2020.

${ }^{21}$ Koentjaraningrat. Sejarah Antropologi I. (Jakarta: UI Pres, 1990), 15-25.

22 Ibid. 
In the theory of religion, the oldest form of religion is based on a human belief in supernatural powers in extraordinary things and be the causes of the emergence of many phenomena that cannot be done by humans. The base of religion is an "emotion" or a "vibration of the soul" that arises because of human admiration for certain things and phenomena that are extraordinary, and which are above ordinary natural forces, namely supernatural or magical powers. ${ }^{23}$ All systems of beliefs and religions in this world are centered on a concept developed by various experts, the concept of religion is divided into five components that have their roles, but are related to one another. These five components are (1) religious emotions; (2) belief systems; (3) the system of rites and ceremonies; (4) ritual and ceremonial equipment; (5) religious people. ${ }^{24}$

The implementation of Ngelinggihang Dewa Hyang ceremony, the main topic of this article, actually reflects these five components of religion. As generally experienced in mots religious activity, this ceremony tends to touch the feelings of Balinese Hindus, primarily the family and relatives of the Pitara. They strongly believe that this ritual will give a sense of security, comfort, peace, and serenity to the life of sekala (real) and niskala (noetic). Since the inception, the main motto of Hinduism is to live in the harmony with other elements of nature. ${ }^{25}$

Friedman divides the legal system into three aspects, namely legal substance, legal structure, and legal culture. In this research, legal culture theory will be primarily used. The legal culture of society is a human thought in an effort to regulate his life, which is known as a written, unwritten, and combinative legal culture of society. ${ }^{26}$

\section{RESULT AND ANALYSIS}

\subsection{Position of Hindu Law in Indonesian Legislation}

According to historical facts, Hinduism is the first and oldest religion in the world that was born and developed in the Sindhu river valley, India. Hinduism has Veda as the holy book and the main source of teaching for its people. ${ }^{27}$ Hinduism was developed firstly in Indonesia in about $4-5^{\text {th }}$ century, which is proved by the existence of the oldest Hinduism kingdom, Kutai Kertanegara, East Borneo (Kalimantan) that is signed by yupa epigraph. ${ }^{28}$ The Vedic scriptures contain various aspects in the common 2006), 57.

23 Agus Salim. Teori Paradigma Penelitian Sosial. (Yogjakarta: Tiara Wacana,

${ }^{24}$ Chris Barker. Cultural Studies: Teori dan Praktek. (Yogjakarta: Bentang, 1999. Pustaka), 15.

25 Praveen Goyal, "Sustainability Evidences from Hindu Philosophy," Evidence Based Management, ${ }^{\text {nd }}$ International Conference on Evidence Based Management (2017): 316.

26 Abdul Halim, Barkatullah. "Budaya Hukum Masyarakat dalam Perspektif Sistem Hukum." Jurnal UKSW 1, no. 1 (2013): 8.

27 Sinaulan, J. H. "Akulturasi Kebudayaan Hindu di Era Multikulturalisme Identitas." Ideas: Jurnal Pendidikan, Sosial, dan Budaya 4, no.2 (2018): 215-224.

${ }^{28}$ Lindayani, Lilik Rita, et al. "The Influence of Hinduism toward the Islamic Practice of Indigenous People in Sulawesi." International Journal of English Literature and Social Sciences (IJELS) 4 (2019). 
niches of human life ranging from religious aspects (relationship with God as the creator of everything that exists), economic, political, and social life aspects, especially Hindu society and world society in general, this is due to the teachings of Hinduism which is universal and flexible and open to every human being. ${ }^{29}$ Not only that, the Veda also studied children, namely regarding the position and various efforts to protect children as stated in several books of the Vedas as the main source of teaching for Hindus. 30 Hinduism is practiced by most of the population in Bali. A total of $3,247,283$ out of $3,890,757$ residents of Bali are Hindus. ${ }^{31}$

Rules derived from Hindu scriptures are called Hindu laws. The existence of Hindu law in Indonesia can be seen from the judicial system during the Dutch colonial period. The court that once existed in the Dutch era was known as the "Rad Kertha Caranegara Court" which was located at Bale Kambang Mayura Cakranegara. The Rad Kertha Court settlle cases related to the Hindu community regarding their problems which are resolved using their Hindu law that is manifested in customary belief and practices.

After Indonesian independence, Hindu courts could no longer be found in the judicial system. The national government eliminated the Rad Kertha, and was replaced by a state court. ${ }^{32}$ According to Article 24 paragraph (2) of the Indonesian Constitution, judicial power is exercised by a Supreme Court and judicial bodies under it in the general court environment, religious court environment, military court environment, state administrative court environment, and by a Constitutional Court. The competence of the religious court as referred to in Article 24 paragraph (2) of the Indonesian Constitution only applies to Muslims and for certain object cases. 33

Recognition of the protection of religion is itself a basic right of citizens and is a legal obligation of the state. Article $28 \mathrm{E}$ paragraph (1) of the Indonesian Constitution states that everyone has the right to embrace a religion and worship according to their religion, choose education and teaching, choose a job, choose citizenship, choose a place to live in the territory of the country and leave it, and have the right to return. Furthermore, Article 29 of the Indonesian Constitution states that Indonesia is based on the belief in the one and only God. The State guarantees the

29 I Made Wirahadi Kusuma and Gede Yoga Satriya Wibawa, "Perlindungan Anak Perspektif Hukum Hindu." Pariksa 2, no. 1 (2020): 68.

30 Ibid.

31 Central Bureau of Statistics of the Republic of Indonesia, "Penduduk Provinsi Bali Menurut Agama yang Dianut Hasil Sensus Penduduk 2010 Population of Bali Province by Religion Based on 2010 Population Census", https:/ / bali.bps.go.id/statictable/2018/02/15/33/penduduk-provinsi-bali-menurutagama-yang-dianut-hasil-sensus-penduduk-2010.html

32 I Nyoman Suarna, I Nyoman Sulastra, and Ni Ketut Windhi Maretha, "Aktualisasi Hukum Hindu Dalam Sistem Hukum di Indonesia," Jatiswara 30 no. 3 (2017): 416.

33 The current religious court in Indonesia only has the authority to examine, adjudicate, decide, and settle cases between people who are Muslim with regards to the issue marriage; inheritance; will; grant; e.waqf; zakat; infaq; shadaqah; and shari'ah economy. See Law of No. 48 of 2009 concerning Judicial Power, Art. 25 (3) and Law of No. 3 of 2006 concerning Amendments to Law No 7 of 1989 concerning Religious Courts, Art. 49. 
freedom of every resident to embrace his religion and to worship according to his religion and belief. Although the state protects religious freedom, Hindu law can only apply if it is interpreted in customary law. ${ }^{34}$

Currently, Hindu law is not a binding law, but is only used as a guide in behavior for Hindus. The values contained in Hindu law are embodied in Balinese customary law. Balinese customary law itself is used in solving civil problems as part of legal pluralism. The potential of Balinese customary law in national development can be viewed from the historical school and sociological jurisprudence flow. Based on these two things, the potential of Balinese customary law is none other than a law that is born and lives in the midst of customary society in Bali. Theoretically, if Balinese customary law is included in the framework of developing national law (especially in Bali), then the effectiveness of legal enforcement can be more guaranteed. ${ }^{35}$ In addition, Hindu law is also used as a guide in the implementation of Hindu religious rituals. Hindu law provides the philosophical meaning of every series of religious ceremonies performed by Hindus in Bali. Hindu law is used as the basis for the life of indigenous people in Bali who are in a customary village organization.

Religious law and customary law are two elements of the law that are closely related. Customary law has specific characteristics and differentiates it from other laws and has been existing and developing in Indonesia, at least for customary society. ${ }^{36}$ Despite customary law does not a type of law that falls into a category of written law as enshrined in the national legislation, the customary community is entitled to give input, both in oral and/or written form, to the substance of a draft of the legislation in which it has interests. ${ }^{37}$ In addition to being applicable through customary law, the values contained in religious teachings can apply as long as they are used in court decisions, namely as a source of law for judges. Judges are obliged to explore, follow, and understand the legal values and the sense of justice that live in society. ${ }^{38}$

\subsection{Hindu Law as the Basis for Implementing Ngelinggihang Dewa Hyang}

Rituals in Bali are generally based on Hindu law that is implemented in the traditions and customs of the local community. In holy book Lontar Purwa Bhumi Kamulan, it is mentioned "Irika mapisan lawan Dewa Hyangnia Nguni," meaning that there Sang Dewa Hyang (God Hyang) unites with Dewa Pitara (the ancestors). All of them are symbolically placed in

34 Some experts view Official customary law as the product of colonial and postcolonial efforts to pigeon-hole customary law into Western systems of law. See Anthony C. Diala, "The concept of living customary law: a critique." The Journal of Legal Pluralism and Unofficial Law 49, no. 2 (2017): 143-165.

35 Anak Agung Istri Ari Atu Dewi, Potensi Hukum Adat: Peran Majelis Desa Pakraman (MDP) Bali dalam Pembangunan Hukum Nasional," Kertha Patrika 38, no. 3 (2016): 255.

36 See Laurensius Arliman, "Hukum Adat Di Indonesia Dalam Pandangan Para Ahli Dan Konsep Pemberlakuannya Di Indonesia," Jurnal Selat 5, no. 2 (2018): 177-190, 179.

37 See of Law No. 12 of 2011 concerning the Formation of Legislation,

38 Law No. 48 of 2009 concerning Judicial Power states, Art. 5 (1) 
Merajan Kamulan, commonly called as Bhatara Hyang Guru. Merajan Kamulan becomes a symbol of primary inspiration for all descendants and place for daily worships. .

Holy book Manawa Dharmasastra III. 203 emphasized that worship should be first directed to the ancestors before continuing to the Gods and Goddes, as a manifestation of the Almighty God. Most Hindus in Bali will firstly pray in Merajan kemulan before doing worship to other temples. Another analogy is guidance for praying in the Besakih mother temple, Karangasem Regency. Balinese Hindus will be in favor of firstly do worship at his/her Pura Padharman, ${ }^{39}$ before visiting and praying at the main temple, called Pura Penataran Agung Besakih. The worship of the ancestor is generally aimed to beg their protection and guidance as well as to strengthen the worship of god and goddess. It is inline with Manawa Dharmasastra. III. 192, that explains: "Akrodhah caucaparah. Satatam brahmacarinah. Nyasta castra mahabhagah. Fitrah purwa dewatah "(The ancestral spirits are the first gods, free from anger. Be careful of their holiness, always be honest, not quarrelsome and rich in virtue).

The worship of Dewa Hyang in the Jero Kuta Customary Village, Batubulan Village is carried out in the Merajan Kemulan or in Paibon 40 temple whose form is called Pelinggih Rong Tiga. Pelinggih ${ }^{41}$ is believed to be the abode of Bapanta ${ }^{42}$, Ibunta ${ }^{43}$ and Raganta ${ }^{44}$. If the deceased person is a male, then it is placed on the right side of rong tiga, called Bapanta, if the woman is placed on the left side, called Ibunta. They are placed there in order to be united with their predecessor ancestors called Raganta. Such beliefs are ancestral inheritance; therefore, the forms of pelinggih are also symbols believed to have supernatural powers and considered sacred because it is purified and performed worship called piodalan ${ }^{45}$ ceremonies. Therefore, the union of ibunta, bapanta and raganta and real family members is established. Simbols for worship is a legacy of ancestors. The family conceives Gods are also in the forms of ancestral spirits in a closely intertwined relationship in which this relationship goes beyond the usual relationship between humans.

The autonomy of customary village to implement Ngelinggihang Dewa Hyang ceremony reflects social integration, religious, and educational functions. From a social perspective, the implementation of this ceremony mainly functions to foster and preserve solidarity and community participation and to tight ikatan menyama braya (a sense of family ties) in the Jero Kuta Customary Village. The family performing Ngelinggihang Dewa Hyang ceremony dissolves in mutual interest, helping each other and working together for the success of this ceremony. Thus, the family

39 A temple based on genealogy and family-lines,

40 Paibon means family shrine.

41 Pelinggih means place of worship, holy object.

42 Bapanta means his father.

43 Ibunta means his mother.

44 Raganta means his body.

45 Piodalan means Hindu religious ceremony which is usually held once every 210 days or 360 days. 
members temporarily put aside interests that are more individualized and remain focused on their common interests. This can further become an adhesive tool for the unity and harmony of the community that is jointly involved in the ceremony. Social integration here occurs to the people or families who carry out the procession of this ceremony. In other words, through the implementation of this ceremony, the feelings of kinship are increasingly tightened.

Next, the religious function can be known from the offerings used as symbols of unlimited heart expression, that cannot be represented by words. The educational function contained in the implementation of Ngelinggihang Dewa Hyang starting with ngaben is to return the elements of the corpse, soul and atman (spirit) to their origin, namely Panca Mahabuta, ${ }^{46}$ Panca Tan Matra, ${ }^{47}$ and Panca Kamendriya ${ }^{48}$ in Bhuwana Agung (the universe), and the purification ceremony for the atman (soul) of deceased people in order to be free from papa klesa (the sin). These series of ceremonies are done in the hope that atman can return to the source of life, according to the subha (good) and asubha (bad) karma. All of the ceremony should be carried out with a very respectful and bhakti (devoted service) to the ancestors. From ngaben to Atma-wedana (Ngelinggihang Dewa Hyang) ceremony, there are five processes. After the samskara or pangaskaran (purification) and ngaben in the grave, Sang Hyang Atma is called Pitra. After Ngeroras ${ }^{49}$ or Ngelinggihang Dewa Hyang accompanied by mendak ring segara (ritual ceremony in the sea or beach) and munggah don bingin ceremony, Sang Hyang Atma is called Pitara. After Maligya and Ngeluwer are accompanied by mendak nuntun 50 Dewa Hyang and nyegara gunung to merajan, Sang Hyang Atma is called Dewata-Dewati (Dewa Hyang). That is all the process of the samskara ${ }^{51}$ ceremony in Pitra Yadnya. The Pitra Yadnya ceremony is a sacred offering performed sincerely before the ancestors. ${ }^{52}$

\subsection{Autonomy of Customary Villages in Ngelinggihang Dewa Hyang Process in Jero Kuta Customary Village}

Customary villages in Bali are built based on the philosophy and values of Hinduism. The authority of the village is an important element in the study of village autonomy. ${ }^{3}$ The new autonomy provided to villages also presents ethnic minorities with an opportunity to return to local forms of

46 Panca Maha Butha are the five elements or basic substances that make up the layers of living things, namely earth, fire, water, wind, space.

47 Panca Tan Matra are the five elements of the seeds of life and the seeds of natural objects, namely sound, taste, touch, sight, and smell

48 Panca Karmendriya means the five senses of the perpetrators of the body, namely the hands, feet, stomach, male genitalia, and female genitalia.

49 Ngeroras means ceremony which is performed on 12 days after the person dies.

50 Mendak nuntun means to find a place.

51 Samskara means ritual or ceremony in Hinduism.

52 Ni Wayan Murniti. "Filosofi Angsa Pada Bale Bukur Dalam Upacara Mamukur di Puri Pemecutan, Kota Denpasar,"Genta Hredaya 3, no.1 (2020): 90.

53 Rosnidar Sembiring, Erna Herlinda, and Suria Ningsih. "Implementation of Autonomy Area through the Implementation of Village Authority," International Journal of Economic Perspectives 11 no. 3 (2017): 1 . 
customary rule. ${ }^{54}$ There are four points of view and understanding of village autonomy, namely as follows: First, the formal legal point of view is often put forward by legal experts. A new village can be called autonomous if it gets a division of authority and finance from the state, so that the village has the authority to manage the government. Second, village autonomy is only understood and affirmed as a form of state recognition of the existence of villages and their rights of origin and traditional customs. This means that the state does not destroy, but rather protects the existence of the village. Third, the concept of 'self-governing community' is often referred to as the equivalent of the phrase 'legal community unity', but so far there has been no adequate elaboration of this foreign concept. Fourth, the romanticlocalistic perspective. Although the law does not define village autonomy, the official discourse emphasizes that villages have 'genuine autonomy' based on local origins and customs. ${ }^{55}$

Customary institutions have the duty and responsibility to foster and preserve culture and customs, and the implementation of religion. ${ }^{56}$ In ensuring the implementation of culture, religion and customs, Pakraman Village has customary law. Customary law is a law that is well understood since it originates with the people in the most direct sense 57 The implementation of Ngelinggihang Dewa Hyang in Jero Kuta customary village which is different from the procession of religious rituals in other areas is the village's dresta.

Customary villages are granted autonomy to carry out activities in accordance with the dresta. ${ }^{58}$ In general, the ceremony of Ngelinggihang Dewa Hyang can be carried out after nganyud sekah (one of ngaben procession) or can be carried out when piodalan is conducted in the temple. This ceremony is held at Sanggah Merajan or Paibon Temple which is adjusted to the usual habits of the families concerned. This ceremony can be led by Sang Sadaka Sulinggih (Hindus highest priest) or at the alit (simple) level can be led by Jro Mangku (hindu priest).

Ngelinggihang Dewa Hyang ceremony held in the Jero Kuta Customary Village is carrying out Nuntun Dewa Hyang ceremony by waiting for the Piodalan Ceremony at their Merajan, where the Dewa Hyang is placed. It is conceived that God of Pitara should be left for some time to get guidance from Ida Sang Hyang Widhi (God). After some time, Nuntun Dewa

54 Christopher R. Duncan. "Mixed outcomes: The impact of regional autonomy and decentralization on indigenous ethnic minorities in Indonesia," Development and Change 38, no. 4 (2007): 720.

55 Ni'matul Huda, "Artikel Kehormatan: Urgensi Pengaturan Desa dalam UndangUndang Dasar Negara Republik Indonesia Tahun 1945." Padjadjaran Journal of Law 4, no. 1 (2017): 8.

56 Lutfi Rumkel, Belinda Sam, and M. Chairul Basrun Umanailo. "Village Head Partnership, Village Consultative Body and Customary Institution in Village Development," Int. J. Sci. Technol. Res 8, no.8 (2019): 1059.

57 Saldi Isra, Ferdi Ferdi, and Hilaire Tegnan. "Rule of Law and Human Rights Challenges in South East Asia: A Case Study of Legal Pluralism in Indonesia," Hasanuddin Law Review 3, no.2 (2017): 123.

58 Bali Provincial Regulation No. 4 of 2019 Concerning Customary Villages in Bali, Art.22 (n). 
Hyang or Ngelinggihang Dewa Hyang ceremony will be held. The essence of this ceremony to be celebrated in Merajan and subsequently became the Bhatara Hyang Guru, that is why the essence of worshiping the God of Pitara is in order to bring Atman closer to Brahman.

In accordance with the dresta of Jero Customary Village, Ngelinggihang Dewa Hyang ceremony series in the Jero Kuta Customary Village is based on the Lontar Purwa Bhumi Kamulan. The stages of the ceremony can be divided into nine stages, in which the first is preparing the ceremonial facilities, especially Daksina Palinggih. 59 Coconut shell which is used for making Daksina Palinggih is generally peeled clean, then smeared with coconut oil made from nyuh gading (one kind of coconut with ivory colour). The coconut becomes the symbol of the place of Sang Dewa Hyang, so that the coconut is peeled clean and there are no traces of the fibers at all. The coconut fiber is a symbol of senses bonding, because it has the status of Dewa Hyang, in which of course it does not have any a symbol of senses bonding. The next stage is to present Sang Dewa Hyang Puja Tarpana by using this Daksina Palinggih.

After this procession, the entire Pratisentana (descendants) offer devotion or pray to Sang Hyang Pitara (ancestors who have been holy). After that, Sang Dewa Hyang is led to be placed in Palinggih Kamulan by placing Daksina Palinggih there. If Sang Dewa Pitara meraga lanang (derived from male ancestor), it is placed on the right side of Palinggih Kamulan. If it is meraga istri (derived from female ancestor), it is placed on the left side of Palinggih Kamulan. Then, Sang Dewa Hyang is given Puja Mantra JayaJaya ${ }^{60}$ (Hindu spell) from Pandita61 who leads this ceremony. After getting Puja Mantra, Pratisentana of Sang Dewa Hyang pray again to Sang Dewa Pitara. The next procession is Pandita gives Puja Pralina and Mantram Penyimpenan (Hindu spell) to invite Sang Dewa Pitara to return in the form of Suksma or Niskala. Daksina Palinggih or Pengadegan of Sang Dewa Pitara is then dilukar (dismantled) and burned. The ash is put into the ivory coconut with kwangen (one of Hindu offerings made from young coconut leaves). The last stage is this ivory coconut is then planted behind Palinggih Kamulan.

Ngelinggihang Dewa Hyang ceremony aims to provide a place for the ancestors to be able to guide their offspring. ${ }^{62}$ The core of banten (type of offering based on Balinese Hindu) for this ceremony consists of only four groups namely Banten Ayaban Dewa Pitara63, Banten Penuntunan ${ }^{64}$ to enshrine Sang Dewa Pitara, Banten Ayaban Ida Bhatara ${ }^{65}$ and Banten

59 Daksina Palinggih means symbol of God.

60 Puja Mantra Jaya-Jaya means spells for inauguration.

61 Pandita means highest priest.

62 Ni Putu Dwiari Suryaningsih, "Upacara Nilapati Bagi Warga Maha Gotra Pasek Sanak Sapta Rsi di Banjar Roban Desa Tulikup Kecamatan Gianyar Kabupaten Gianyar (Perspektif Pendidikan Agama Hindu)," Jurnal Penelitian Agama Hindu 1, no. 2 (2017): 312315.

63 Banten Ayaban Dewa Pitara means offerings for the ancestors.

${ }^{64}$ Banten Penuntunan means offerings that deliver.

65 Banten Ayaban Ida Bhatara means offerings offered to gods. 
placed in front of Pandita. Based on the structural functionalization theory, the Ngelinggihang Dewa Hyang ceremony is carried out through the same perception by the community in one customary village and carried out through cooperation by the community in the customary village concerned.

\subsection{Community Perception in Ngelinggihang Dewa Hyang Ceremony in Jero Kuta Customary Village}

Assessment of the understanding of society and the social environment is a study from the perspective of legal culture, a reflexion of legal awareness of the legal subjects of a community as a whole. 66 The legal culture of the Hindu community in Bali shows that all systems of life are based on Hindu religious teachings. Sang Hyang Widhi or God Almighty has no particular form. He is very big, very small, light and delicate and he permeates and completes the universe. Therefore, he is everywhere. God does not have a certain form because he is sarining parama tattwa ${ }^{67}$, which is the essence of philosophy in the Vedas called Sat. Humans are not able to imagine his form because he is not tangible, so he is called Acintya meaning unthinkable. Sang Hyang Widhi (God) cannot be seen, but is only described in words and can be felt like sacred vibrations when concentrating on worshiping him.

The existence of Hindu Law has a very important role in increasing the insight of Hindus in knowing the legal rules contained in the Vedic scriptures. Knowing Hindu law as part of the teachings in Hinduism can increase Hindu understanding. ${ }^{68}$ Humans indeed try to describe the form of Sang Hyang Widhi in their imagination, as the God is believed a tangible form. Hinduism knows the limits of human psychology. Not all humans can meditate on God in abstract form without any real physical form. In order to guide the mind to God, the existence of a manifestation is valuable assistance.

Hinduism recognizes the importance of symbols to facilitate its devotees to connect with God. These symbols are manifested in pujamantra, ${ }^{69}$ in wijaksara, ${ }^{70}$ in mudras, ${ }^{71}$ and in the forms of upakara or banten (the offerings), in ceremonial stages and also in other manifestations. Banten (the offerings) is a means to revive the connection between the body and nature. ${ }^{72}$ Hindu religious teachings are translated through the implementation of traditional religious ceremonies.

66 Sunaryati Hartono. 1976. Peranan Kesadaran Hukum Masyarakat dalam Pembaharuan Hukum. Bandung: Binacipta, 3.

67 Sarining parama tattwa means the essence of ethical teachings.

68 Ida Ayu Aryani Kemenuh. "31 Memahami Hukum Hindu Untuk Mewujudkan Sumber Daya Manusia Hindu Yang Berkualitas." Pariksa 3, no. 2 (2020): 32.

69 Puja-mantra means sacred chant.

70 Wijaksara are characters, letters, syllables; sacred syllables that are believed to have the power of chastity.

71 Mudras means a hand gesture that guides the energy flow to specific areas of the brain

72 I Gusti Agung Paramita, "Bencana, agama dan kearifan lokal," Dharmasmrti: Jurnal Ilmu Agama dan Kebudayaan 18, no.1 (2018): 39. 
Legal culture is one part of human culture that is so broad. Legal culture is the same general response from certain societies to legal symptoms. This response is a unified view of legal values and behavior. Legal culture shows the pattern of individual behavior as members of society which describes the same response (orientation) to the legal life lived by the community concerned. ${ }^{73}$ In this study, the legal culture of the community can be seen from the perspective of the traditional village community to implement dresta at the Ngelinggihang Dewa Hyang ceremony.

\subsubsection{Understanding Through Interaction with the Family Environment}

The Hindu community in Bali has the responsibility to pay homage and worship ancestral spirits. ${ }^{74}$ Ngelinggihang Dewa Hyang ceremony is a continuation of Ngaben ceremony. At Ngaben ceremony, the spirit of the deceased can be called kedas (clean) while at the Ngelinggihang Dewa Hyang ceremony, the spirit of the deceased person is purified to be free from earthly shackles and is believed to reach moksa (the liberation from the cycle of death and rebirth) and obtain a calm and peaceful atmosphere and pretisentana (the family left behind) can live a peaceful and prosperous life because they mragatin (have done their duty).

The ceremony aimed at the ancestors is very noble in nature. Because for Hindus, ancestral spirits after being purified are dewa (Gods). Pitra Yadnya conducted in the form of Ngelinggihang Dewa Hyang ceremony is a way to pay debts to the ancestors or Pitra Rna. This belief is carried out by the community with the guidance of Sulinggih in the form of a ceremony. Paying debts to those who have died (ancestors) and those who are still carrying out their obligations in this life will obtain peace and serenity. Understanding Pitra Yadnya is an effort to pay the moral duty.

\subsubsection{Understanding Through Interaction with Communities}

The concept is the body must be immediately cremated (aben) to return panca maha butha to God. ${ }^{75}$ Public understanding of Ngelinggihang Dewa Hyang in the series of pitra yadnya ceremonies is a form of the power of human imagination in the process of a spiritual journey to get to the realm of God. The symbols of Hinduism which are commonly used in every Hindu religious ceremony are called Banten (offering) which cannot be separated from religious activities. All of these symbols are inseparable from

73 Iman Pasu Marganda Hadiarto Purba, "Penguatan budaya hukum masyarakat untuk menghasilkan kewarganegaraan transformatif." Jurnal Civics: Media Kajian Kewarganegaraan 14, no. 2 (2017): 146-153.

${ }^{74}$ AA Sagung Ngurah Indradewi, "Pergeseran Fungsi Pura di Bali: Dari Ritual ke Pertemuan Politik," Jurnal Kajian Bali (Journal of Bali Studies) 6, no.2 (2016): 196.

75 I Dewa Made Suara, I. Putu Gelgel, and I. Wayan Suka Yasa. "Pitra yadnya implementation for Hindu heroes," International journal of social sciences and humanities 2, no.3 (2018): 137. 
the beliefs of the people in the Jero Kuta Customary Village which still adhere to a very strong gugon tuwon (believing in something that is considered beyond nature) system which is inherited from generation to generation and is common to be implemented. From this description, after interacting with the community in Jero Kuta Customary Village, in the implementation of Ngelinggihang Dewa Hyang ceremony, the true understanding of the symbols in the ceremony is not understood by all people deeply. However, in the implementation of this ceremony, this fact does not reduce the meaning literally.

Sociocultural life depends on the level of social solidarity or social interaction in a society. Community activities in preparing Ngelinggihang Dewa Hyang ceremony always occur in unity between the community and the Customary Village Prajuru (the village officers). The principle of mutual cooperation and unity is so thick that there is a synergy in carrying out a process of preparation for the ceremony which is of course with the interaction between communities. In general, the process of community interaction in the Jero Kuta Customary Village in this ceremony is very good with the evidence that the ceremony runs well in accordance with community expectation.

Ngelinggihang Dewa Hyang is a ceremony that has functions namely enable the spirit to reach Moksa and as the payment of moral duty or obligations to the ancestors. Every person is obliged to carry out his yadnya as the implementation of the Tri Rna (three depts that have been carried since the birth) teachings. In general, the debt is an obligation and must be paid. This debt is not paid with money or some kind of valuables as generally in economic transactions but with the ceremony of Yadnya.

Ngelinggihang Dewa Hyang ceremony is one part of the Pitra Yadnya ceremony. It is a human effort in fostering religious relations between the descendants (Pretisentana) and their ancestors. This ceremony contains a lot of hope including the souls of the ancestors to be purified, live in peace, and always in happiness. For those who are still alive, it is expected that they can get the grave so that they can live in a decent, safe, and prosperous condition in this world. The ceremony is held in the hope that the souls of the ancestors can be purified in peace and vice versa to those left behind to be given the blessings of a decent life in order to build a peaceful family, community and environment.

Ngelinggihang Dewa Hyang ceremony is a pitra yadnya ceremony which is performed after the Ngaben ceremony to increase the sanctity of the spirit to become dewa pitara. Dewa-pitara means pitara that has existed in dewa (Gods) realm, namely swah-loka (realm of the ancestors), but that does not mean that pitara is a God. Because dewa pitara that is full of purity is in the realm of the Gods and also functions to guide and protect the lives of their offspring, that is why dewa pitara is also given the title of 
bhatara kawitan 76 adored at pelinggih kemulan or kawitan by their descendants.

Sang Hyang Atma in the journey to the three realms (bhur loka ${ }^{77}$, bwah loka ${ }^{78}$, and swah loka79) is like out of transcendental. Atman heads for a higher and holy realm. The atman (soul) pilgrimage to the higher realms is carried out by the ceremonial leader with the spell of mantra penuntunan containing the request to present the pitara, to purify the pitara, to offer the pitara the offerings, to guide the pitara to be calm down, and to ask swarga (heaven) or moksa ${ }^{80}$ for the pitara with the swargantu ${ }^{81}$ and moksantu mantra. 82

The usual ritual held in Ngelinggihang Dewa Hyang is pangesengan puspalingga (burning) ceremony. Before doing it, the pandita pleaded with the puja to burn lara, roga and papa of the pitara and to remove the fetters the atman, ${ }^{83}$ hoping that the pitara can receive the holy light of Sang Hyang Paramatma. ${ }^{84}$ The next step is offer respectfully the banten pengresikan (cleaning offering) as a symbol that pitara is outwardly purified, continued by presenting Sekul Liwet as a meal for pitara. Afterward, the Pandita delivers holy pawisik $k^{85}$ as a guidance to the sacred niskala realm. Lastly, the priest performs puja tirtha pralina ${ }^{86}$ to transfer atman into a more sacred world of sunia. ${ }^{87}$

The public has not yet fully understood about Ngelinggihang Dewa Hyang ceremony. Several factors cause the lack of public understanding in this ceremony, among others:

1. Differences in community understanding of the existence of the Ngelinggihang Dewa Hyang ceremony. The village community thinks more practically about the existence and implementation of the ceremony. They are less concerned about the meaning contained in it because of the superficial understanding of the community.

2. Ignorance of the community. The community's ignorance about the importance of understanding the ceremonies is due to the lack of comprehension and community awareness of the knowledge of the ceremony. As an instance, when dharma wacana (the explanation of

76 Bhatara kawitan means the ancestors who have preceded us and are already holy.

77 Bhur Loka means realm to the gods.

${ }_{78}$ Bwah Loka means realm to human nature.

79 Swah Loka means the realm of the ancestors.

80 Moksa is freedom from worldly bonds and also from the cycle of reincarnation.

81 Swargantu means got heaven.

82 Moksantu mantra is a prayer for a deceased person to become one with God

See: I Nyoman Singgin Wikarman. Ngaben, Upacara dari Tingkatan Sederhana sampai Utama. (Surabaya: Paramita, 2002), 48.

83 Atman means little spark from God.

84 Sang Hyang Paramatma means God Almighty.

85 Pawisik means get a whisper from the supernatural.

86 Puja tirtha praline means holy water that is sprinkled when people die.

87 Sunia means the realm of divinity or divinity as perfection and freedom.

See: Wiana. Menuju Bali Jagadhita, Tri Hita Karana Sehari-hari. (Denpasar : Bali Post, 2004), 150. 
hindus teaching) held by prajuru desa (village officers), they are less enthusiastic to follow it.

3. Education Level. The level of education plays an important role in one's understanding of the problems that occur in society. From several interviews with the community, education constraints greatly affect people's understanding of this ceremony so that the implementation is less than perfect without a correct understanding.

4. The development of globalization in people's life. The influence of the development of globalization in the community has led to developments in various fields of people's life. This condition causes shifts in the mindset and behavior of the general public. People tend to follow the flow of globalization and begin to leave the traditions and customs that exist in the customary village.

The community understands the symbols in Ngelinggihang Dewa Hyang Ceremony through interactions conducted in the community. Starting from paruman (meeting) to determine the day of the ceremony, banten or offerings needed and how the community work system so that the ceremony can run well in accordance with the common goals and desires. The paruman is usually led by bendesa adat (the head of customary village) or kelian adat (customary leader in each banjar, a small unit of community). During the paruman, the community members are informed about the plan to hold the ceremony, so they will be voluntarily joined in preparing the ceremony. It is expected that they will have an understanding that a generousity and goodwill based on sradha and bhakti (devotional service) are the essences in supporting the conducting of the ceremony.

\section{CONCLUSION}

Hindu law does not have an explicit position in national law, but is used as the guideline for Balinese customary law. Hindu law establishes an obligation on humans to carry out responsibilities to their ancestors through the holding of the Ngaben ceremony along with a series of other ceremonies.

Hindu legal philosophy teaches that every person has an obligation to free his ancestors from worldly ties through the performance of religious ceremonies. The implementation of Ngelinggahang Dewa Hyang ritual originates from Hindu law as enshrined in the Manawa Dharmasastra, a holy book that provides guidelines in implementing religious ceremonies carried out by Hindus.

In Bali, this Hindu law is generally incorporated into the customary law of Desa adat (customary village). This type of village has the autonomy to carry out religious, traditional, and social activities in accordance with the dresta (custom). This entails that each customary village may have differences in terms of how the custom should be executed in practice. This paper used Ngelinggihang Dewa Hyang ceremony in the Jero Kuta customary village as an example of how rituals are different from other villages. This customary village conducts the Nyegara Gunung Ceremony and the Ngalinggihang Dewa Hyang Ceremony on different days. It can be 
assessed that the ceremony implies social integration, religious, and educational functions.

The impact of people's understanding on the implementation of Ngelinggihang Dewa Hyang ceremony can be assessed in the interaction in family and community scope that reflects the public perception regarding this ceremony. It can be discovered that the society does not fully understand the meaning of this religious procession due to the following factors; differences in community understanding of the existence of the Ngelinggihang Dewa Hyang ceremony; ignorance of the community, education Level, and the development of globalization in people's life.

\section{ACKNOWLEDGEMENT}

Author would like to thank I Gusti Bagus Sugriwa State Hindu University for providing research funding in 2018 and all the facilities provided at the social science laboratory.

\section{BIBLIOGRAPHY}

\section{Book}

Barker, Chris. Cultural Studies: Teori dan Praktek. Yogjakarta: Bentang Pustaka, 1999.

Hamidi. Metode Penelitian Kuantitatif. Malang: Universitas Muhammadiyah, 2004.

Hartono, Sunaryati. Peranan Kesadaran Hukum Masyarakat dalam Pembaharuan Hukum. Bandung: Binacipta, 1976.

Koentjaraningrat. Sejarah Antropologi I. Jakarta: UI Press, 1990.

Salim, Agus. Teori Paradigma Penelitian Sosial. Yogjakarta: Tiara Wacana, 2006.

Wiana, Menuju Bali Jagadhita, Tri Hita Karana Sehari-hari. Denpasar : Bali Post, 2004.

Wikarman, I Nyoman Singgin. Ngaben, Upacara dari Tingkatan Sederhana sampai Utama. Surabaya: Paramita, 2002.

\section{Journal Article}

Abdul Halim, Barkatullah. "Budaya Hukum Masyarakat dalam Perspektif Sistem Hukum." Jurnal UKSW 1, no. 1 (2013).

Agusintadewi, Ni Ketut, "Pola Spasial Permukiman Tradisional Bali Aga di Desa Sekardadi, Kintamani, "RUAS (Review of Urbanism and Architectural Studies) 14, no.2 (2017): $47-57$. http://dx.doi.org/10.21776/ub.ruas.2016.014.02.5

Dewi, Anak Agung Istri Ari Atu. "Potensi Hukum Adat: Peran Majelis Desa Pakraman (MDP) Bali dalam Pembangunan Hukum Nasional." Kertha $\begin{array}{lllll}\text { Patrika 38, no. } & 3 & \text { (2016): }\end{array}$ https:// doi.org/10.24843/KP.2016.v38.i03.p05

Diala, Anthony C., "The concept of living customary law: a critique." The Journal of Legal Pluralism and Unofficial Law 49, no. 2 (2017): 143165. https://doi.org/10.1080/07329113.2017.1331301 
Duncan, Christopher R.. "Mixed outcomes: The impact of regional autonomy and decentralization on indigenous ethnic minorities in Indonesia," Development and Change 38, no. 4 (2007).

Duncan, Christopher R. "Mixed outcomes: The impact of regional autonomy and decentralization on indigenous ethnic minorities in Indonesia." Development and change 38, no. 4 (2007): 711-733. https://doi.org/10.1111/j.1467-7660.2007.00430.x

Goyal, Praveen. "Sustainability Evidences from Hindu Philosophy." Evidence Based Management, $2{ }^{\text {nd }}$ International Conference on Evidence Based Management (2017), 315-365.

Huda, Ni'matul, "Artikel Kehormatan: Urgensi Pengaturan Desa dalam Undang-Undang Dasar Negara Republik Indonesia Tahun 1945." Padjadjaran Journal of Law 4, no.1 (2017): 1-18.

Indradewi, AA Sagung Ngurah. "Pergeseran Fungsi Pura di Bali: Dari Ritual ke Pertemuan Politik." Jurnal Kajian Bali (Journal of Bali Studies) 6, no. 2 (2016): 195-208.

Isra, Saldi, Ferdi Ferdi, and Hilaire Tegnan. "Rule of Law and Human Rights Challenges in South East Asia: A Case Study of Legal Pluralism in Indonesia." Hasanuddin Law Review 3, no. 2 (2017): 117-140. http://dx.doi.org/10.20956/halrev.v3i2.1081

Kemenuh, Ida Ayu Aryani. "31 Memahami Hukum Hindu Untuk Mewujudkan Sumber Daya Manusia Hindu Yang Berkualitas." Pariksa 3, No. 2 (2020): 32.

Kiriana, I. Nyoman. "Ngaben Conception In Lontar Siwa Tattwa Purana." Vidyottama Sanatana: International Journal of Hindu Science and Religious Studies 1, no. 2 (2017): 84-92.

Kusuma, I. Made Wirahadi, and Gede Yoga Satriya Wibawa. "Perlindungan Anak Perspektif Hukum Hindu." Pariksa 2, no. 1 (2020).

Arliman, Laurensius. "Hukum Adat Di Indonesia Dalam Pandangan Para Ahli Dan Konsep Pemberlakuannya Di Indonesia." Jurnal Selat 5, no. 2 (2018): 177-190.

Lestawi, I Nengah and Dewi Bunga. "The Role of Customary Law in the Forest Preservation in Bali." Journal of Landscape Ecology 13, no. 1 (2020): 25-41. https://doi.org/10.2478/jlecol-2020-0002

Lindayani, Lilik Rita, et al. "The Influence of Hinduism toward the Islamic Practice of Indigenous People in Sulawesi." International Journal of English Literature and Social Sciences (IJELS) 4, (2019). https://dx.doi.org/10.22161/ijels.4.1.31

Murniti, Ni Wayan. "Filosofi Angsa Pada Bale Bukur Dalam Upacara Mamukur Di Puri Pemecutan, Kota Denpasar," Genta Hredaya 3 no. 1 (2020).

Narottama, Nararya, "Spiritual tourism: A case study of foreigners' participation in the Pitrayajna ceremony in the Desa Pakraman of Muncan, Selat, Karangasem, Bali," E-Journal of Tourism 3, no.1. (2016): 33-44. https:// doi.org/10.24922/eot.v3i1.20841

Ndun, Hanna Christine, Sarah Suttor, and I. Gusti Agung Ayu Dike Widhiyaastuti. "Does Customary Law Discriminate Balinese Women's Inheritance Rights?." Udayana Journal of Law and Culture 2, no. 1 (2018): 97-114. https://doi.org/10.24843/UJLC.2018.v02.i01.p05 
Paramita, I Gusti Agung. "Bencana, agama dan kearifan lokal." Dharmasmrti: Jurnal Ilmu Agama Dan Kebudayaan 18, no. 1 (2018): 36-44.

Purba, Iman Pasu Marganda Hadiarto. "Penguatan budaya hukum masyarakat untuk menghasilkan kewarganegaraan transformatif." Jurnal Civics: Media Kajian Kewarganegaraan 14, no.2 (2017): 146-153.

Putri, Luh Putu Yeyen Karista and Eric Gordon Withnall. "Protecting the Village Credit Institution: Should Traditional Communities Adopt Modern Financial Management Practices?." Udayana Journal of Law and Culture 2, no. 2: 115-139. https://doi.org/10.24843/UJLC.2018.v02.i02.p01

Rumkel, Lutfi, Belinda Sam, and M. Chairul Basrun Umanailo. "Village Head Partnership, Village Consultative Body and Customary Institution in Village Development." Int. J. Sci. Technol. Res 8, no. 8 (2019): 1058-1063.

Sabardi, Lalu. "Konstruksi Makna Yuridis Masyarakat Hukum Adat dalam Pasal 18B UUDN RI Tahun 1945 untuk Identifikasi Adanya Masyarakat Hukum Adat." Jurnal Hukum \& Pembangunan 44, no. 2 (2014): 170-196.

Saraswati, A. A. O., and Paul Memmott. "The Child Misses Its Mother\|Balinese Place Experience of the Ngaben Ritual Event." Journal of Basic and Applied Scientific Research 4, no. 5 (2014): 1-5.

Sembiring, Rosnidar, Erna Herlinda, and Suria Ningsih. "Implementation of autonomy area through the implementation of village authority." Journal of Economic \& Management Perspectives 11, no. 3 (2017): 5-11.

Sinaulan, J. H. "Akulturasi Kebudayaan Hindu Di Era Multikulturalisme Identitas." Ideas: Jurnal Pendidikan, Sosial, dan Budaya 4, no. 2 (2018): 215-224.

Suara, I. Dewa Made, I. Putu Gelgel, and I. Wayan Suka Yasa. "Pitra yadnya implementation for Hindu heroes." International journal of social sciences and humanities 2, no. 3 (2018): 136-148.

Suarna, I Nyoman, I Nyoman Sulastra, and Ni Ketut Windhi Maretha. "Aktualisasi Hukum Hindu Dalam Sistem Hukum di Indonesia." Jatiswara 30 no. 3 (2017).

Sumarto. "Creative Economic Management of Tangkit Lama Village Sungai Gelam Sub-District Muara Jambi District." HUNAFA: Jurnal Studia Islamika 15, no. 2 (2018): 323-339.

Suryaningsih, Ni Putu Dwiari. "Upacara Nilapati Bagi Warga Maha Gotra Pasek Sanak Sapta Rsi di Banjar Roban Desa Tulikup Kecamatan Gianyar Kabupaten Gianyar (Perspektif Pendidikan Agama Hindu)." Jurnal Penelitian Agama Hindu 1, no. 2 (2017): 312-318.

Syamsudin. "Beban masyarakat adat menghadapi hukum negara." Jurnal Hukum Ius Quia Iustum 15, no.3 (2008): 338-351.

Untara, I Made Gami Sandi. "Kosmologi Hindu Dalam Bhagavadgìtā." Jñānasiddhânta: Jurnal Teologi Hindu,” 1, no.1 (2019). 
Widana, I. Gusti Ketut. "Filosofi Ritual Hindu, Pergeseran Antara Konsep dan Konteks." Dharmasmrti: Jurnal Imu Agama dan Kebudayaan 19, no. 2 (2019): 28-34.

Widyantara, I., Made Minggu, I. Wijaya, Ketut Kasta Arya, Ni Komang Arini Styawati, and I. Nyoman Sumardika. "Environment Dispute Resolution Through Awig-Awig (Customary Law)." JL Pol'y \& Globalization 70 (2018): 75-79.

\section{Law and Regulation of the Republic of Indonesia}

The 1945 Constitution of the Republic of Indonesia

Law of No. 3 of 2006 concerning Amendments to Law No. 7 of 1989 concerning Religious Courts

Law of No. 48 of 2009 concerning Judicial Power

Law No. 12 of 2011 concerning the Formation of Legislation

Bali Provincial Regulation No. 4 of 2019 Concerning Customary Villages in Bali

\section{Website Content}

Central Bureau of Statistics of the Republic of Indonesia, "Penduduk Provinsi Bali Menurut Agama yang Dianut Hasil Sensus Penduduk 2010 Population of Bali Province by Religion Based on 2010 Population Census", Retreived at https:/ / bali.bps.go.id/statictable/2018/02/15/33/pendudukprovinsi-bali-menurut-agama-yang-dianut-hasil-sensus-penduduk2010.html 